\section{Pengaruh Ekstrak Daun Pedada (Sonneratia caseolaris) sebagai Antihiperkolesterolmia pada Mencit (Mus musculus)}

\author{
Ramlah
}

\section{BIONATURE}

p-ISSN 1411 - 4720

e-ISSN 2654 - 5160

Abstract. This study was conducted to determine the effect of extract leaf pedada (Sonneratia caseolaris) to total cholesterol levels of mice (Mus musculus) male ICR strain. Leaf pedada extracted using $96 \%$ methanol by maceration. This study is a completely randomized design (CRD), which consists of 5 treatments and 5 replicates the normal group (distilled water), positive group (Simvastatin), a group of leaf pedada extract at a dose of 125, 250 and $500 \mathrm{mg} / \mathrm{kg}$. The extract was dissolved using Carboxy Methyl Cellulose (CMC) $0.5 \%$ and given orally in mice which had previously been given a high cholesterol feed. The results showed the methanol extract of leaves cemba with the dose of $500 \mathrm{mg} / \mathrm{kg}$ hads the highest effectiveness in lowering total cholesterol levels in mice which have hypercholesterolemia with a 30,20\% percentage drop. These results indicate that of the giving leaf extract pedada (Sonneratia caseolaris) able to lower total cholesterol levels of mice (Mus musculus) male hypercholesterolaemia.

Keywords: Antihipercholesterolemia, total cholesterol, Methanol extract of leaf pedada (Sonneratia caseolaris), mice (Mus musculus) ICR male.

Ramlah

Universitas Negeri Makassar Indonesia golongan statin tergolong ke dalam salah satu obat penurun kadar kolesterol. Golongan obat ini bekerja sebagai 
penghambat enzim pembentukan kolesterol yaitu $H M G$ CoA reductase inhibitors, sehingga pembentukan kolesterol di dalam tubuh terhambat. Obat-obat tersebut memiliki mekanisme kerja, indikasi, efektifitas dan efek samping yang berbeda-beda (Arief et al 2012).

Sesuai sifat alaminya, manusia selalu berusaha mencukupi kebutuhannya dengan memanfaatkan segala sesuatu yang ada disekitarnya. Termasuk untuk kebutuhan pangan dan obatobatan. Tanaman obat sudah dipakai sejak nenek moyang kita untuk mengatasi masalah kesehatan mereka baik untuk pencegahan maupun penyembuhan suatu penyakit. Selain lebih murah, diyakini bahwa obat-obatan alamiah tidak memiliki efek samping, berbeda dengan obat-obat kimiawi.

Penelitian yang terdahulu beberapa daun yang mengandung flavonoid yang dapat menurunkan kadar kolesterol seperti ditunjukkan (Ratnawati et al 2014) bahwa daun salam yang mengandung flavonoid dapat menurunkan kadar kolesterol. Begitupula dilakukan oleh (Quntary, 2015) menggunakan daun murbei yang mengandung flavonoid terbukti dapat menurunkan kadar kolesterol pada tikus putih. Penelitian selanjutnya dilakukan oleh (Maryani, 2016) dengan menggunakan daun kayu kuning.

Salah satu tanaman yang juga dapat digunakan sebagai obat tradisional yaitu tanaman yang berasal dari mangrove pedada (Sonneratia caseolaris), tanaman ini diketahui mengandung antioksidan. Tanaman ini mengandung senyawa alkaloid, flavonoid, glikosida, safonin, dan fenol (Yulianis et al. 2015).

Berdasarkan uraian diatas maka perlu dikaji sejauh mana pengaruh ekstrak metanol daun pedada Sonneratia caseolaris terhadap penurunan kolesterol pada mencit jantan yang mengalami hiperkolesterol.

\section{Metode Penelitian}

\section{Desain Penelitian}

Hewan uji yang digunakan berupa mencit (Mus musculus) galur ICR berjenis kelamin jantan, sehat, dan beraktivitas normal. Mencit umur 2-3 bulan sebanyak 25 ekor dibagi menjadi 5 kelompok perlakuan yang masing-masing terdiri atas 5 ekor mencit dalam satu kandang. Bobot badan mencit berkisar 20 - 30-gram yang di bagi menjadi 5 kelompok perlakuan.

\section{Rancangan Percobaan}

Mencit diadaptasikan selama 2 minggu dengan diberi pakan komersial berupa pakan standar tepung ADII dan air minum secara ad libitum sebelum diberi pakan perlakuan (pakan kolesterol berupa bubuk kuning telur) agar cara hidup dan makanannya menjadi seragam. Pada minggu ketiga, mencit dikelompokkan sesuai kelompoknya masing-masing. Kelompok mencit ditentukan berdasarkan bobot badan yang dibagi ke dalam 5 kelompok perlakuan.

Adapun kelompok perlakuannya seperti berikut:

a. Kelompok negatif: kelompok mencit yang diberikan pakan standar dan aquadest selama masa percobaan.

b. Kelompok positif: kelompok mencit diberi pakan standar selama 2 minggu pertama (masa adaptasi). Kemudian 2 minggu berikutnya diberi pakan tinggi kolesterol (campuran pakan ADII dengan kuning telur dengan perbandingan 9:1 secara ad libitum). Setelah 2 minggu, mencit diberi simvastatin dengan dosis $10 \mathrm{mg}$ sebanyak $0,2 \mathrm{~mL} /$ hari selama 2 minggu.

c. Kelompok III: kelompok mencit diberi pakan standar selama 2 minggu pertama (masa adaptasi). Kemudian 2 minggu berikutnya diberi pakan tinggi kolesterol (campuran pakan ADII dengan kuning telur dengan perbandingan 9:1 secara ad libitum). Setelah 2 minggu, mencit diberi ekstrak daun pedada (Sonneratia caseolaris) dengan dosis $125 \mathrm{mg} / \mathrm{kg}$ BB mencit sebanyak 0,2 $\mathrm{mL} /$ hari selama 2 minggu.

d. Kelompok IV: kelompok mencit diberi pakan standar selama 2 minggu pertama (masa adaptasi). Kemudian 2 minggu berikutnya diberi pakan tinggi kolesterol (campuran pakan ADII dengan kuning telur dengan perbandingan 9:1 secara ad libitum). Setelah 2 minggu, mencit diberi 
ekstrak daun pedada (Sonneratia caseolaris) dengan dosis $250 \mathrm{mg} / \mathrm{kg}$ BB mencit sebanyak 0,2 $\mathrm{mL} /$ hari selama minggu.

e. Kelompok V: kelompok mencit diberi pakan standar selama 2 minggu pertama (masa adaptasi). Kemudian 2 minggu berikutnya diberi pakan tinggi kolesterol (campuran pakan ADII dengan kuning telur dengan perbandingan 9:1 secara ad libitum). Setelah 2 minggu, mencit diberi ekstrak daun pedada (Sonneratia caseolaris) dengan dosis $500 \mathrm{mg} / \mathrm{kg}$ BB mencit sebanyak 0,2 $\mathrm{mL} /$ hari selama 2 minggu.

\section{Alat dan Bahan}

Alat-alat yang digunakan pada penelitian ini adalah oven, alat pengukur kadar kolesterol total (Nesco), gelas kimia (Pyrex) $250 \mathrm{ml}$ dan $1000 \mathrm{ml}$, labu Erlenmeyer (Pyrex), neraca analitik, neraca Ohaus, gelas ukur (Pyrex), batang pengaduk, gunting, rang kawat uji, corong Buhner, blender, spoit, oven, syringe, magnetic stirrer, waterbaht. Daun pedada (Sonneratia caseolaris), simvastatin, metanol, mencit (Mus musculus) galur ICR jantan berumur 2-3 bulan berat badan 20-30 gram, kuning telur, pakan mencit AD II, alkohol 70\%, kertas saring Wathmen 41, strip kolesterol (Nesco), kapas dan tissue, CMC.

\section{Sterilisasi Alat}

Untuk sterilisasi alat digunakan oven. Hal ini bertujuan agar alat-alat yang digunakan bebas dari mikroorganisme.

\section{Prosedur Penelitian}

\section{a. Pembuatan Ekstrak Metanol Daun Pedada (Sonneratia caseolaris)}

Daun pedada yang diambil adalah daun yang muda. Selanjutnya daun pedada sebanyak 4000 gr dicuci pada air mengalir sampai bersih, kemudian dikeringkan dengan cara diangin-anginkan pada suhu kamar. Daun pedada yang sudah kering diblender sampai halus. Serbuk daun pedada diambil sebanyak 500-gram kemudian direndam (maserasi) menggunakan pelarut metanol sebanyak 3,5 L selama $3 \times 24$ jam pada suhu kamar, perendaman diulangi sebanyak tiga kali. Hasil rendemen atau maserat disaring menggunakan kertas Whatman, selanjutnya dievaporasi menggunakan waterbath pada suhu $40 C^{0}$ hingga diperoleh ekstrak kental (Wagiswari, 2016).

\section{b. Pembuatan Pakan Tinggi Kolesterol}

Pakan kolesterol yang digunakan dalam penelitian ini dibuat dari campuran kuning telur ayam ras dan pakan standar ADII dengan perbandingan 1:9. Kuning telur ayam ras direbus selama 30 menit atau sampai matang, kemudian kuning telur yang telah matang dilumatkan di atas loyang sampai menjadi bubuk. Kemudian diratakan tipis diatas aluminium foil. Kuning telur kemudian dioven pada suhu $40^{\circ} \mathrm{C}-45^{\circ} \mathrm{C}$ selama 24 jam. Pakan standar ADII ditimbang dan diblender kemudian dicampur dengan tepung kuning telur serta diaduk hingga tercampur rata. Pakan kolesterol yang telah jadi kemudian dibungkus dengan plastik bening agar tidak terkontaminasi.

\section{c. Pembuatan Sediaan Ekstrak daun pedada (Sonneratia caseolaris)}

Sebelum ekstrak daun pedada (Sonneratia caseolaris) diberikan kepada hewan uji hal pertama yang harus dilakukan yaitu menimbang ekstrak daun pedada sesuai dengan dosis yang diperlukan menggunakan neraca analitik. Kedua menimbang 0,5 g CMC (Carboxy Methyl Cellulose) dengan menggunakan neraca analitik, kemudian dilarutkan kedalam aquades $100 \mathrm{ml}$. Selanjutnya masing-masing dosis ekstrak daun pedada dilarutkan kedalam CMC kemudian dihomogenkan dengan menggunakan magnetic stirrer.

\section{d. Proses Pemberian Eksrak Daun Pedada (Sonneratia caseolaris) ke Mencit (Mus musculus) Jantan}

Mencit (Mus musculus) jantan dipegang dan dijepit bagian tengkuk dengan jari tangan. Mencit (Mus musculus) jantan dikondisikan senyaman mungkin agar tidak mengalami stress. Mengisi 
syringe dengan ekstrak daun Pedada (Sonneratia caseolaris) sebanyak 0,2 mL kemudian diberikan secara oral ke hewan uji mencit (Mus musculus) jantan.

\section{e. Proses Pengambilan Sampel Darah Pada Mencit (Mus musculus) Jantan}

Ekor mencit (Mus musculus) jantan diusapkan alkohol 70\% dengan menggunakan kapas. Ekor mencit (Mus musculus) jantan dijulurkan dan dipotong sekitar $1 \mathrm{~mm}$ dari ujung ekor dengan gunting yang steril. Darah ditampung dalam strip kolesterol sebanyak $15 \mu \mathrm{L}$. Kadar kolesterol diuji dengan menggunakan alat pengukur kolesterol multicheck merek Nesco. Ekor mencit jantan (Mus musculus) diolesi alkohol agar darah tidak mengalir secara terus-menerus dan diberi antibiotik.

\section{f. Masa Pengukuran Kadar Kolesterol Darah}

Setiap 14 hari dilakukan pengukuran kadar kolesterol. Pengukuran kadar dilakukan setelah masa adaptasi sebagai kadar kolesterol awal, masa pemberian pakan kolesterol serta setelah diberikan perlakuan (setelah mencit diberi ekstrak daun pedada).

\section{g. Analisis Data}

Data yang diperoleh dari hasi pengamatan dianalisa dengan menggunakan analisis menggunakan ANOVA dengan taraf kepercayaan $\alpha=0,05$. Kemudian dilanjutkan dengan uji lanjutan Duncan dengan menggunakan aplikasi SPSS 2.0.

\section{Hasil Penelitian}

Tabel 1. Rata-Rata Kadar Kolesterol Mencit Jantan Sebelum dan Setelah Perlakuan

\begin{tabular}{|c|c|c|c|c|c|}
\hline \multirow[b]{2}{*}{ No. } & \multirow[b]{2}{*}{ Perlakuan } & \multicolumn{3}{|c|}{$\begin{array}{c}\text { Rata-Rata Kadar Kolesterol (mg/dL) Mencit } \\
\text { Jantan (Mus musculus) }\end{array}$} & \multirow{2}{*}{$\begin{array}{c}\text { Persentase } \\
\text { penurunan kadar } \\
\text { kolesterol (mg/dL) } \\
\text { mencit (Mus } \\
\text { musculus) jantan }\end{array}$} \\
\hline & & $\begin{array}{c}\text { Pengukuran } \\
\text { pertama } \\
\text { (hari ke 15) }\end{array}$ & $\begin{array}{c}\text { Pengukuran } \\
\text { kedua } \\
\text { (hari ke 29) }\end{array}$ & $\begin{array}{c}\text { Pengukuran } \\
\text { ketiga } \\
\text { (hari ke 43) }\end{array}$ & \\
\hline 1 & Kontrol negatif & $99,20^{\text {a }}$ & $114,20^{\mathrm{a}}$ & $108,60^{a}$ & $4,05 \%$ \\
\hline 2 & $\begin{array}{l}\text { Kontrol positif } \\
\text { (Simvastatin) }\end{array}$ & $95,20^{\mathrm{a}}$ & $142^{\mathrm{b}}$ & $111,40^{a}$ & $22.11 \%$ \\
\hline 3 & P1125 mg/kg BB & $98,80^{a}$ & $155,20^{\mathrm{b}}$ & $127,60^{\mathrm{a}}$ & $19.94 \%$ \\
\hline 4 & P2 $250 \mathrm{mg} / \mathrm{kg} \mathrm{BB}$ & $101,20^{\mathrm{a}}$ & $151,20^{\mathrm{b}}$ & $118,40^{\mathrm{a}}$ & $23,69 \%$ \\
\hline 5 & P3 $500 \mathrm{mg} / \mathrm{kg} \mathrm{BB}$ & $100,20^{\mathrm{a}}$ & $154,80^{\mathrm{b}}$ & $113^{\mathrm{a}}$ & $30,20 \%$ \\
\hline
\end{tabular}

Keterangan: Huruf yang sama dalam satu kolom menunjukkan "berbeda tidak nyata". Huruf yang berbeda dalam satu kolom menunjukkan "berbeda nyata". Huruf yang berbeda antar kolom yang satu dengan kolom yang lain menunjukkan" berbeda nyata".

Hasil analisis menggunakan ANOVA (Analysis of Variance) yang dilanjutkan dengan uji Duncan $\alpha 0,05$ dapat dilihat pada Lampiran 1. Pada tabel 4.1 menunjukkan rata-rata kadar kolesterol total (mg/dL) mencit (Mus musculus) jantan pada pengukuran pertama antara semua kelompok perlakuan (kontrol negatif, kontrol positif, kelompok yang diberikan ekstrak daun pedada (Sonneratia caseolaris) dengan dosis berturut-turut $125 \mathrm{mg} / \mathrm{kg} \mathrm{BB}, 250 \mathrm{mg} / \mathrm{kg} \mathrm{BB}$, dan 500 $\mathrm{mg} / \mathrm{kg}$ BB mencit (Mus musculus) menunjukkan hasil yang berbeda tidak nyata. Rata-rata kadar kolesterol total (mg/dL) mencit (Mus musculus) jantan yang paling tinggi yakni pada kelompok perlakuan P2 $250 \mathrm{mg} / \mathrm{kg}$ BB sebesar 101,2 mg/dL dan rata-rata kadar kolesterol total (mg/dL) yang paling rendah pada kelompok perlakuan kontol positif sebesar 95,2 mg/dL.

Rata-rata kadar kolesterol total (mg/dL) mencit (Mus musculus) jantan pada pengukuran kedua menujukkan hasil yang berbeda nyata antara kontrol negatif dengan kontrol positif dan kelompok yang diberikan ekstrak daun pedada (Sonneratia caseolaris) dosis $125 \mathrm{mg} / \mathrm{kg} \mathrm{BB}, 250$ 
$\mathrm{mg} / \mathrm{kg}$ BB dan $500 \mathrm{mg} / \mathrm{kg}$ BB mencit (Mus musculus) jantan. Kadar kolesterol total (mg/dL) yang paling tinggi yakni pada kelompok P1 $125 \mathrm{mg} / \mathrm{kg}$ BB mencit (Mus musculus) jantan sebesar 155,2 $\mathrm{mg} / \mathrm{dL}$ dan rata-rata kadar kolesterol total $(\mathrm{mg} / \mathrm{dL})$ yang paling rendah pada kontrol negatif sebesar $114,2 \mathrm{mg} / \mathrm{dL}$.

Rata-rata kadar kolesterol total (mg/dL) mencit (Mus musculus) jantan pada pengukuran ketiga antara semua kelompok perlakuan (kontrol negatif, kontrol positif, kelompok yang diberikan ekstrak daun pedada (Sonneratia caseolaris) dengan dosis berturut-turut $125 \mathrm{mg} / \mathrm{kg} \mathrm{BB}, 250$ $\mathrm{mg} / \mathrm{kg} \mathrm{BB}$, dan $500 \mathrm{mg} / \mathrm{kg} \mathrm{BB}$ mencit (Mus musculus)), menujukkan hasil yang berbeda tidak nyata. Kadar kolesterol total (mg/dL) mencit (Mus musculus) jantan yang paling tinggi yakni pada kelompok P1 125 mg/kg BB sebesar 127,6 mg/dL dan rata-rata kadar kolesterol total (mg/dL) mencit (Mus musculus) jantan yang paling rendah pada kontol negatif sebesar 108,6 mg/dL.

Penurunan kadar kolesterol total mencit (Mus musculus) pada setiap perlakuan setelah pemberian ekstrak daun pedada (Sonneratia caseolaris) yaitu pada kontrol negatif (aquadest) terlihat adanya penurunan kadar kolesterol total mencit sebesar 4,05\%. Penurunan kadar kolesterol pada kontrol positif (Simvastatin) sebesar 22,11\%. Pada kelompok ekstrak daun pedada (Sonneratia caseolaris) dosis $125 \mathrm{mg} / \mathrm{kg}$ BB mengalami penurunan sebesar 19,94\%, ekstrak daun pedada (Sonneratia caseolaris) dosis $250 \mathrm{mg} / \mathrm{kg}$ BB mengalami penurunan sebesar $23,69 \%$ dan dosis $500 \mathrm{mg} / \mathrm{kg}$ BB mengalami penurunan sebesar 30,20\%.

Induksi hiperkolesterol dapat dilakukan dengan pemberian pakan kolesterol berupa campuran pakan standar 90\% dan lemak 10\%. Pada kelompok mencit yang diberikan pakan hiperkolesterol mengalami peningkatan kadar kolesterol. Hal ini menunjukkan bahwa pemberian kuning telur pada pakan hewan uji mencit (Mus musculus) dapat meningkatkan kadar kolesterol. Ramadhan (2011) menyatakan bahwa pemberian pakan standar dan tinggi kolesterol mampu meningkatkan kadar kolesterol total dari 85 mg/dL sampai $115 \mathrm{mg} / \mathrm{dL}$ dan kadar trigliserid dari 87 $\mathrm{mg} / \mathrm{dL}$ menjadi $127 \mathrm{mg} / \mathrm{dl}$.

Pada kontrol negatif rata-rata kadar kolesterol total pada pengukuran ketiga mengalami penurunan yang lebih sedikit jika dibandingkan dengan kontrol positif (simvastatin), diketahui bahwa simvastatin merupakan obat golongan statin yang telah banyak digunakan untuk antihiperkolesterolmia yang mampu menurunkan kadar kolesterol total (Quntari, 2015), namun obat golongan statin diketahui memiliki efek samping diantaranya miopati, tremor, vertigo, parestesia, gangguan saraf pusat, cemas, konstipasi dan kembung (Arief et al 2012). Pada kelompok ekstrak daun pedada (Sonneratia caseolaris) juga mengalami penurunan. Pada dosis 125 $\mathrm{mg} / \mathrm{kg}$ BB mengalami penurunan kadar kolesterol yang lebih sedikit jika dibandingkan dengan dosis $250 \mathrm{mg} / \mathrm{kg}$ BB dan dosis $500 \mathrm{mg} / \mathrm{kg} \mathrm{BB}$. Penurunan kadar kolesterol total pada kelompok ekstrak daun pedada (Sonneratia caseolaris) masih berada pada batas normal. Menurut Erni et all 2014) rata-rata kadar kolesterol mencit (Mus musculus) jantan yang masih normal yaitu 40-130 $\mathrm{mg} / \mathrm{dL}$.

Hal ini menandakan bahwa pemberian ekstrak daun pedada (Sonneratia caseolaris), dengan berbagai dosis $125 \mathrm{mg} / \mathrm{kg} \mathrm{BB}, 250 \mathrm{mg} / \mathrm{kg}$ BB dan $500 \mathrm{mg} / \mathrm{kg} \mathrm{BB}$ ) pada mencit (Mus musculus) jantan dapat menurunkan kadar kolesterol total mencit (Mus musculus) jantan yang mengalami hiperkolesterolemia. Dosis yang paling efektif untuk menurunkan kadar kolesterol total mencit (Mus musculus) jantan yakni $500 \mathrm{mg} / \mathrm{kg}$ BB dengan penurunan sebesar 41,8 mg/dL atau 30,20 \%. Kemampuan ekstrak daun pedada (Sonneratia caseolaris) dalam menurunkan kadar kolesterol total mencit (Mus musculus) jantan karena adanya senyawa metabolit sekunder yang diduga merupakan senyawa golongan asam lemak, sterol, hidrokarbon, dan dua flavonoid yaitu luteolin dan luteolin 7$O-\beta$ glukosida (Herwinda, 2013), dimana diketahui bahwa senyawa flavonoid yang terkandung pada tumbuhan biasanya berfungsi sebagai antioksidan.

Flavonoid dapat menurunkan sintesis kolesterol dengan cara menghambat kerja dari HMGKoA reduktase, yang merupakan enzim yang berperan dalam pembentukan kolesterol di hati. Selain itu, flavonoid juga dapat menurunkan aktivitas enzim acyl-coA cholesterol acyltransferase (ACAT), yang merupakan enzim yang berperan dalam pengaturan absorbsi kolesterol di usus dan produksi lipoprotein di hati (Maryani, 2016). Menurut Rofidah (2015), Flavonoid dapat mempengaruhi proses metabolisme kolesterol LDL dengan meningkatkan kemampuan LDL untuk 
terikat pada reseptornya. LDL yang terikat pada reseptor akan termetabolisme menjadi kolesterol ester di jaringan. HDL akan mengikat kolesterol ester yang terdapat pada jaringan dan kemudian dieksresi ke usus halus. Selain itu flavonoid juga memiliki aktivitas menurunkan LDL oksidase. Flavonoid dapat mengurangi LDL peroksidasi lipid, mengurangi stres oksidatif makrofag dengan menghambat oksigenase seluler dan mengaktifkan antioksidan seluler. Dengan demikian, flavonoid merupakan antioksidan alami yang mampu melindungi terhadap peroksidasi lipid dalam arteri dan lipoprotein. Dengan menurunnya LDL oksidase maka pembentukkan sel busa akan terhambat sehingga menurunkan resiko terjadinya aterosklerosis.

Hasil penelitian ini menunjukkan bahwa ektrak daun pedada (Sonneratia caseolaris) dapat menurunkan kadar kolesterol total pada mencit (Mus musculus) jantan yang mengalami hiperkolesterol sehingga berpotensi sebagai obat herbal untuk menurunkan kadar kolesterol total. Dosis yang paling efektif dalam menurunkan kadar kolesterol yaitu pada dosis $500 \mathrm{mg} / \mathrm{kg} \mathrm{BB}$.

\section{Kesimpulan}

Berdasarkan hasil penelitian yang telah dilakukan maka dapat disimpulkan bahwa pemberian ekstrak daun pedada (Sonneratia caseolaris) mampu menurunkan kadar kolesterol total mencit (Mus musculus) jantan yang mengalami hiperkolesterolemia.

\section{Referensi}

Arief, M.I., Riky.N., Indra T B., \& Muhammad B.H. (2012). Potensi Bunga Karamunting (Melastoma malabathricum L.) terhadap Kadar Kolesterol Total dan Trigelserida pada Tikus Putih Jantan Hiperlipidemia yang Diiunduksi Propiltiourasil. Kalimantan Selatan: Progran Studi Kedokteran. Fak. Kedokteran Unlam.

Erni., A. Mu'nisa., A. \& Faridah, A.A. (2014). Pengaruh Pemberian Minyak Mandar yang Ditambahkan Bubuk Daun Sukun (Arthocarpus altilis) terhadap Kadar Kolesterol Mencit (Mus musculus). Jurusan Biologi. FMIPA. Universitas Negeri Makassar.

Ferry, I.G.P.A., Manuntun, M., \& Ni M.P. (2015). Efektifitas Antosianin Kulit Buah Jamblang (Syzygium cumini) sebagai Penurun Low Dinsety Lipoprotein Darah Tikus Wistar yang Mengalami Hiperkolesterolmia. Denpasar :Jurusan Kimia FMIPA. Universitas Udayana.

Maryani, P.E., Evi U U., \& Ema R. (2016). Pengaruh Ekstrak Metanol Daun Kayu Kuning (Arcangelisia flava (L.) Merr.) terhadap Kadar Kolesterol Total dan Trigliserida Tikus Hiperlipidemia. Jember: Fakultas Farmasi. Universitas Jember.

Quntary, L.I. (2015). Pengaruh Pemberian Kombi Nasi Ekstrak Etanol Daun Murbei (Morus Alba L.) dengan Simvastatin Terhadap Kolesterol Total Tikus Putih Hiperkolesterolemia. Surakarta: Fakultas Farmasi. Universitas Muhammadiyah Surakarta.

Ramadhan, F.F. (2011). Pengaruh Pemberian Nata De Coco Terhadap Kadar Kolesterol Total dan Trigliserida pada Tikus Hiperkolesterolemia. Semarang: Fakultas Kedokteran. Universitas Diponegoro.

Ratnawati, H., Rosnaem., \& Irene C. (2014). Efek Ekstrak Etanol Daun Salam (Syzygium polyanthum ( Wight Walp) Terhadap Kadar Kolestrol Total Serum Tikus Wistar yang Diinduksi Pakan Tinggi Lemak Dibandingkan Simvastatin. Bandung : Fakultas Kedokteran. Universitas Kristen Maranatha.

Rofida, S., Ahmad, F., \& Endah, F. (2015). Aktivitas Antihiperlipidemia Ekstrak Etanol Daun Annona Squamosa L. Prodi Farmasi. Fakultas Ilmu Kesehatan. Universitas Muhammadiyah Malang. 
Wahjoeni, R., Yanti, M.M., \& Michaela, E.P. (2016). Gambaran Kadar Kolesterol Total Darah pada Mahasiswa Vegetarian Lacto-Ovo. Fakultas Kedokteran. Universtias Sam Ratulangi Manado.

Wagiswari, M.G. (2011). Efek Antifungi Ekstrak Etanolik Seledri (Apium graveolensl.), Kemangi (Ocimum bacilicum L.) Serta Campurannya Terhadap Pertumbuhan Candida albicans In Vitro. Surakarta. Fakultas Kedokteran. Universitas Sebelas Maret.

Wignjosoesastro, C., Zita A., \& Dewi. (2014). Pengaruh Bawang Putih (Allium sativum) Terhadap Pencegahan Hiperkolesterolmia pada Tikus. Jakarta Utara: Fakultas Kedokteran Unika Atma Jaya.

Yulianis., Mudyawati L., M R. (2015). Isolasi Senyawa Dari Fraksi Etil Asetat Daun Pedada (Sonneratia caseolaris L.) dan Uji Aktivitas Antioksidan. Jambi : Fakultas Sains Dan Teknologi. Universitas Jambi.

Ramlah

S,Si. Prodi Jurusan Biologi FMIPA, Universitas Negeri Makassar E-mail: ramlah.bio27@gmail.com 